\title{
Charcoal kilns as a source of data on the past iron industry (an example from the
} River Czarna valley, Central Poland)

\author{
Paweł Rutkiewicz*1, Ireneusz Malik ${ }^{1}$, Małgorzata Wistuba ${ }^{1}$, Agata Sady² \\ 1Department of Reconstructing Environmental Change, Faculty of Earth Sciences, Będzińska Str. 60, 41-200 Sosnowiec, \\ University of Silesia in Katowice, Poland \\ ${ }^{2}$ Laboratory of Bioarcheology, Archeology Department, Silesian Museum, Dobrowolskiego Str. 1, 40-205 Katowice, Poland \\ E-mail address (*corresponding author): rutkiewiczpawel33@gmail.com
}

\begin{abstract}
Charcoal was the primary fuel used for iron smelting and processing until the end of the 19th century. It was produced through burning piles of wood called charcoal kilns. The aim of the study was to identify and record traces of charcoal kilns related to past ironworks in the valley of the River Czarna (Małopolska Upland, Central Poland). Detailed analysis was conducted in areas adjacent to historical centres of iron processing in Maleniec, Kołoniec and Machory. A quantitative analysis of the traces of charcoal kilns in the topography was done based on DEM from airborne LiDAR. Soil profiles were analysed at the sites where traces of charcoal kilns were identified from DEM. Radiocarbon dating and palaeobotanical analyses were performed for selected charcoal from kiln remnants. In the study area we identified over 11,500 charcoal kilns. The radiocarbon age of these charcoals indicate that the charcoal kilns under study were used in the $15^{\text {th }}, 18^{\text {th }}$ and $19^{\text {th }}$ century. Thus the results suggest that the iron industry in the studied area is c 100 years older than the historical written sources indicate. Palaeobotanical analyses show that coniferous trees were used for charcoal production. The large number of traces of charcoal kilns and their wide spatial distribution indicate that past charcoal production has had a significant impact on the environment and landscape change in the River Czarna valley and adjacent areas.
\end{abstract}

KEY WORDS: iron processing, charcoal production, LiDAR, radiocarbon dating

ARTICLE HISTORY: received 5 May 2017; received in revised form 13 July 2017; accepted 17 July 2017

\section{Introduction}

Until the end of the $19^{\text {th }}$ century charcoal was the primary fuel used for iron smelting and processing (GROENEWOUDT, 2007) as it provided the high temperature necessary for melting iron and its ores (GALE, 2003). Charcoal production for iron smelting was common in forested areas of Europe (GROENEWOUDT, 2007). Charcoal was produced by burning wood piled in the form of charcoal kilns (GosZYK, 2001). At first charcoal kilns were placed in pits dug in the ground, $2 \mathrm{~m}$ deep and $2 \mathrm{~m}$ wide. Pits were filled with wood pieces, next covered with soil and turf, and finally the construction was set alight (BiElenin, 1960; MARSZAŁEK \& KuSIAK, 2013). Between the $16^{\text {th }}$ and the $19^{\text {th }}$ century charcoal in Europe was produced with the use of more advanced charcoal kilns (RöSLER ET AL., 2012). They were larger and composed of selected wood pieces $(60-70 \mathrm{~cm}$ long). Wood was piled into dome-shaped mounds. Next, the construction was covered with turf and moss, and then this was set alight. Air inflow into the kiln was constantly controlled during the production process and thus instead of wood burning dry distillation occurred. Charcoal production in one kiln took 12-15 days on average (RAJMAN, 2009).

Historical studies on charcoal kilns traces have so far been carried out both in the context of their morphometry and their spatial distribution. Analyses of the remnants of charcoal kilns were also used in studies on the history of the iron industry and mining (BAL ET AL., 2015; DELHON ET AL., 2017; DUPIN ET AL., 2017; GROENEWOUDT, 2007; LUDEMANN, 2010, 2011, 2012; RAAB ET AL., 2015; RÖSLER ET AL., 2012), 
soil properties (BAL ET AL., 2015; BORCHARD, 2014), deforestation and identification of past extent of forests (KNAPP ET AL., 2013; LUDEMANN, 2002, 2003; LUDEMANN ET AL., 2004; NELLE, 2003; SCHOCH, 2012; TOLKSDORF ET AL., 2015). In Poland studies on charcoal kilns focused on methods of kiln identification using GIS tools (BAKUŁA ET AL., 2014; ZAPŁATA ET AL., 2013, 2014) and dating the age of iron smelters (MALIK ET AL., 2014, 2015).

In many areas of Central Europe iron smelters were located in the bottoms of river valleys (MALIK ET AL., 2015). The iron industry was powered by water wheels and some descriptions of such smelting complexes can be found in historical sources and in the field. The valley of the River Czarna (Małopolska Upland, Central Poland) is one of the areas where iron smelters existed in the past. The aim of our study was to identify and record traces of charcoal kilns related to past ironworks in the River Czarna valley. An attempt has also been made to check the possibility of dating selected charcoal kilns and to determine tree species and character of the wood used for charcoal production.

\section{Study area}

The River Czarna (170-346 m a.s.l.) is a sandbed meandering river which flows through the northern part of the Małopolska Upland (Central Poland). It is $87.9 \mathrm{~km}$ long and drains the area of $972.6 \mathrm{~km}^{2}$ (Fig. 1). Catchment bedrock is composed of Jurassic and Triassic sandstones and Jurassic limestones covered with tills of the Riss glaciation (KONDRACKI, 2000).

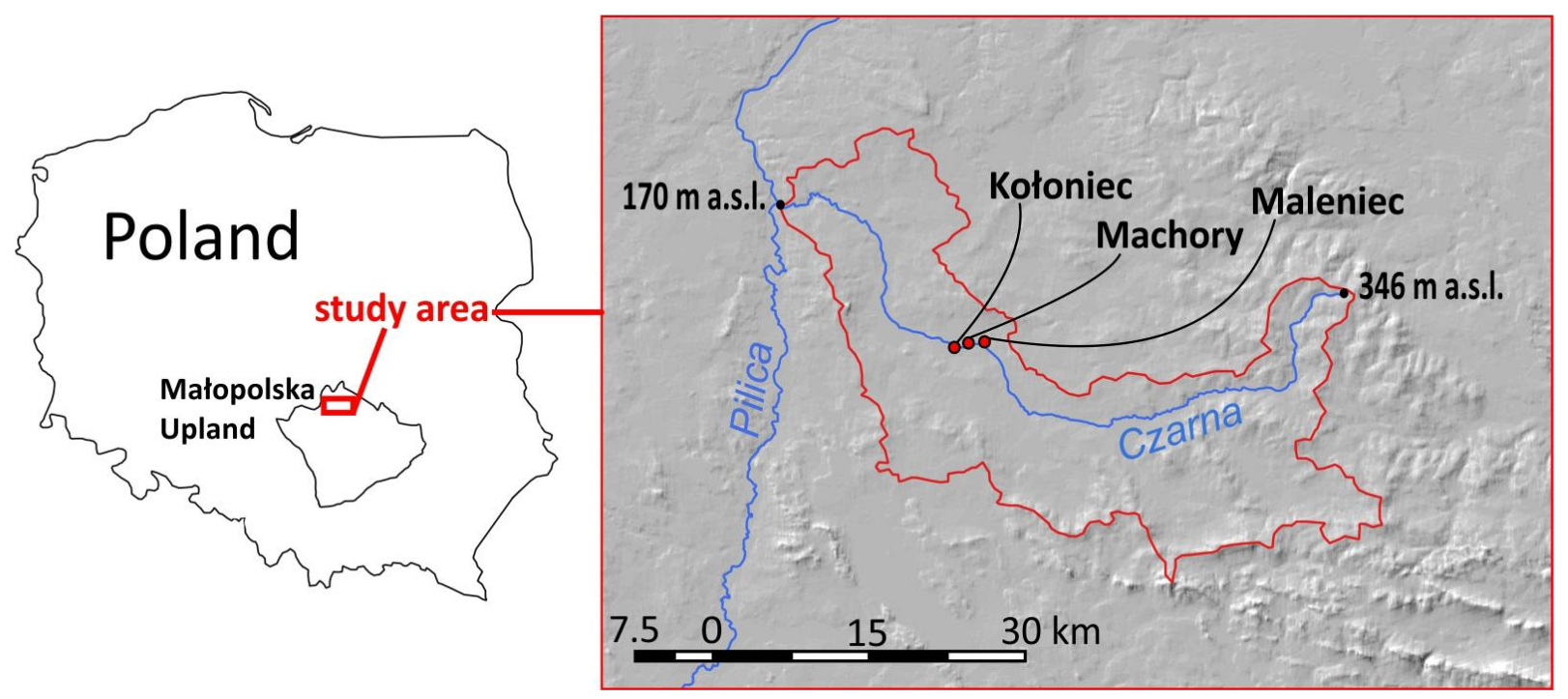

Fig. 1. Location of the historical ironworks under study (Maleniec, Kołoniec and Machory) in Poland and in the catchment of the River Czarna (catchment boundary marked in red)

Iron ores occur over vast areas in the upper and middle part of the Czarna catchment, as clayey siderite interbedding in the Jurassic sandstones (SZCZEGÓŁOWA MAPA GEOLOGICZA, 1955, 1965). They have been exploited for several centuries (16 ${ }^{\text {th }}-19^{\text {th }}$ century) which led to the development of a system of mine shafts in the Czarna catchment. Shallow iron bog ores were also common in the Czarna catchment in the past. They were exploited directly from the ground surface (RADWAN, 1963; GĄSIOROWSKA, 1937). The River Czarna flows mostly through forests. The most common species is pine (c $90 \%$ of all stands). Other species are larch, spruce and fir with minor occurrence of beech, oak, elm, ash, maple, birch, alder, aspen and lime. Approximately $90 \%$ of the forest area is humanplanted. Detailed analyses were conducted for the area around a group of historical ironworks in
Maleniec, Kołoniec and Machory (at c 53-55 km of the River Czarna) (Fig. 1).

\section{History of iron industry in the study area}

In the valley of the River Czarna c 250 ironworks existed between the $16^{\text {th }}$ and $19^{\text {th }}$ century. The development of the iron industry in the area was caused by the occurrence of iron ores and vast forests. Wood was used for the construction of foundry buildings and most importantly, for charcoal production. Charcoal was the primary fuel for all kinds of metallurgical processes conducted in the study area until the end of the $19^{\text {th }}$ century (CHєOPEK, 2015a).

The iron smelters in Machory and Kołoniec were powered by water wheels and were already in existence in the $16^{\text {th }}$ century (RADWAN, 1963). 
Both smelters were mentioned in historical documents in 1510-1577 (ZIENTARA, 1954). Later, blast furnaces were constructed probably at the same sites where old smelters operated. More advanced methods of metallurgical production were introduced. The blast furnace in Machory was built before 1783, and in Kołoniec before 1784 (KUBICKI \& SALETRA, 2013). Pig iron from the above mentioned blast furnaces was processed at the factory in Maleniec. In 1833, the first puddling furnace in the area of the present Polish territory was constructed in Machory (ORŁOWSKI, 1931). According to archival maps, both in Machory and in Kołoniec, smelting ponds existed (Fig. 2). The dam of the pond in Machory was broken during the flood in 1923. Its size remains unknown, however, its remnants are partially visible in the topography of the River Czarna valley. The dam in Kołoniec was broken in 1939 (HERBST, 1954). There are currently breeding ponds in the area where the steelworks in Kołoniec were located.

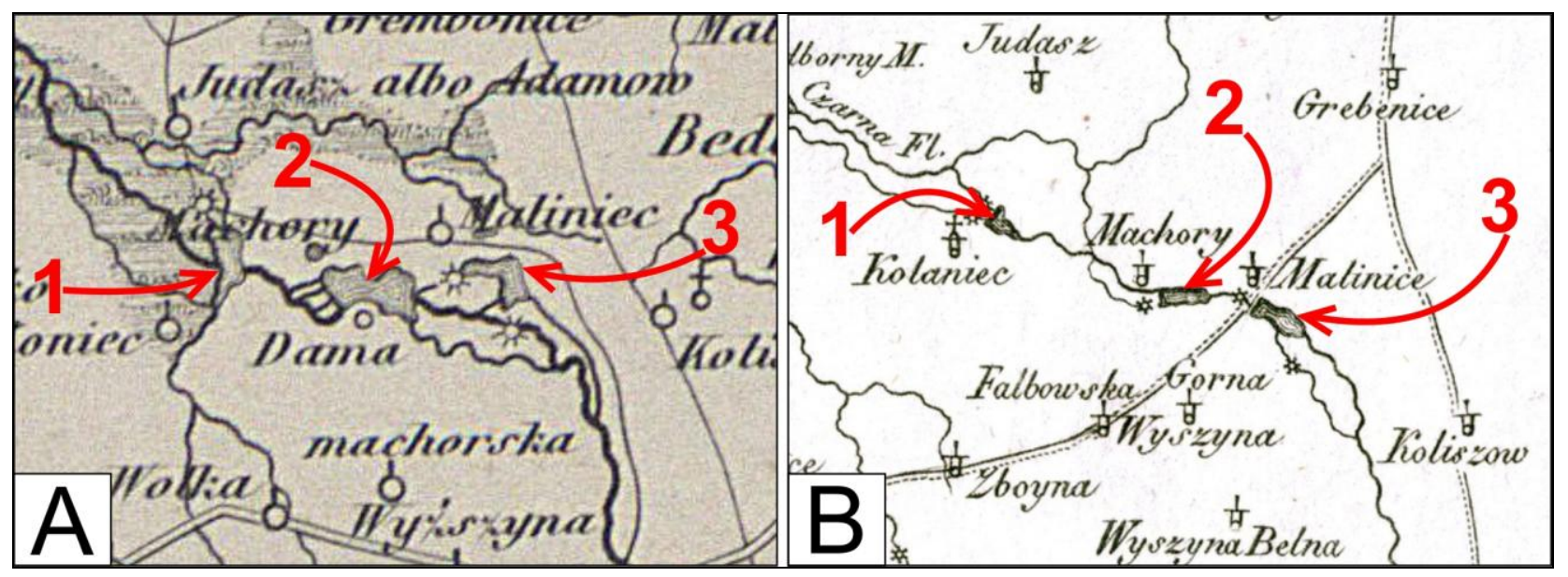

Fig. 2. Former smelter ponds in Kołoniec (1), Machory (2) and Maleniec (3) on archival maps. A - 1803, Gilly Special Karte von Südpreussen, 1:150 000; B - 1859, W. Chrzanowski, Karta dawnej Polski, 1:300 000

Detailed data are available on the factory in Maleniec. The $1603 \mathrm{~m}$ long dam was built in 1782 to accumulate water from the River Czarna needed to turn water wheels. The smelting pond in Maleniec still exists, nowadays coving an area of 20 hectares. Eight finery forges with water-powered hammers operated in Maleniec. The factory significantly expanded in the 1830s and 1840s. At that time Maleniec was the most modern metallurgical plant in the Russian-occupied Kingdom of Poland. The factory was partially destroyed during the fights of September 1939. After the Second World War, in 1945, the demand for products from the Maleniec iron factory increased considerably. Over time due to low profitability, lack of investment and hard working conditions the decision to stop production was made in 1967 (СНŁOРЕК, 2015b,c).

\section{Methods of the study}

\subsection{Using LiDAR data and GIS tools to detect remnants of charcoal kilns}

We obtained digital elevation mode (DEM) from aerial laser scanning LiDAR data interpolated in a $1 \mathrm{~m}$ grid for the area within a distance of c $4 \mathrm{~km}$ from the Czarna channel. Data were obtained for both sides of the valley along its full length, from river source to mouth (Fig. 3). Particular attention was given to areas around former ironworks where charcoal kilns occur particularly often. LiDAR data $(0.2 \mathrm{~m}$ spatial resolution) were obtained from Central Office for Geodetic and Cartographic Documentation (CODGiK).

DEM images were generated using various 5 visualization tools to find as many traces of charcoal kilns as possible. The following tools were used: hillshading, Multiple Hillshading from several directions, positive and negative Openness (OPPOS and OPNEG - illumination techniques based on the degree of openness of the relief at one point) (MAYORAL ET AL., 2017), local relief model (LRM which represents local small-scale elevation differences after removing the large-scale landscape forms from the data) (HESSE, 2010), Sky-View Factor (SVF- an illumination technique based on the calculation of the visible sky from each position) (MAYORAL ET AL., 2017). Based on obtained DEM images a quantitative and spatial analysis of the presence of charcoal kilns was conducted for the area under study (Fig. 3). We used hillshading as a primary source of information. Other tools were used in case of problems with identifying charcoal kilns from hillshading images, in particular when we observed a high density of items concentrated in a small area. 


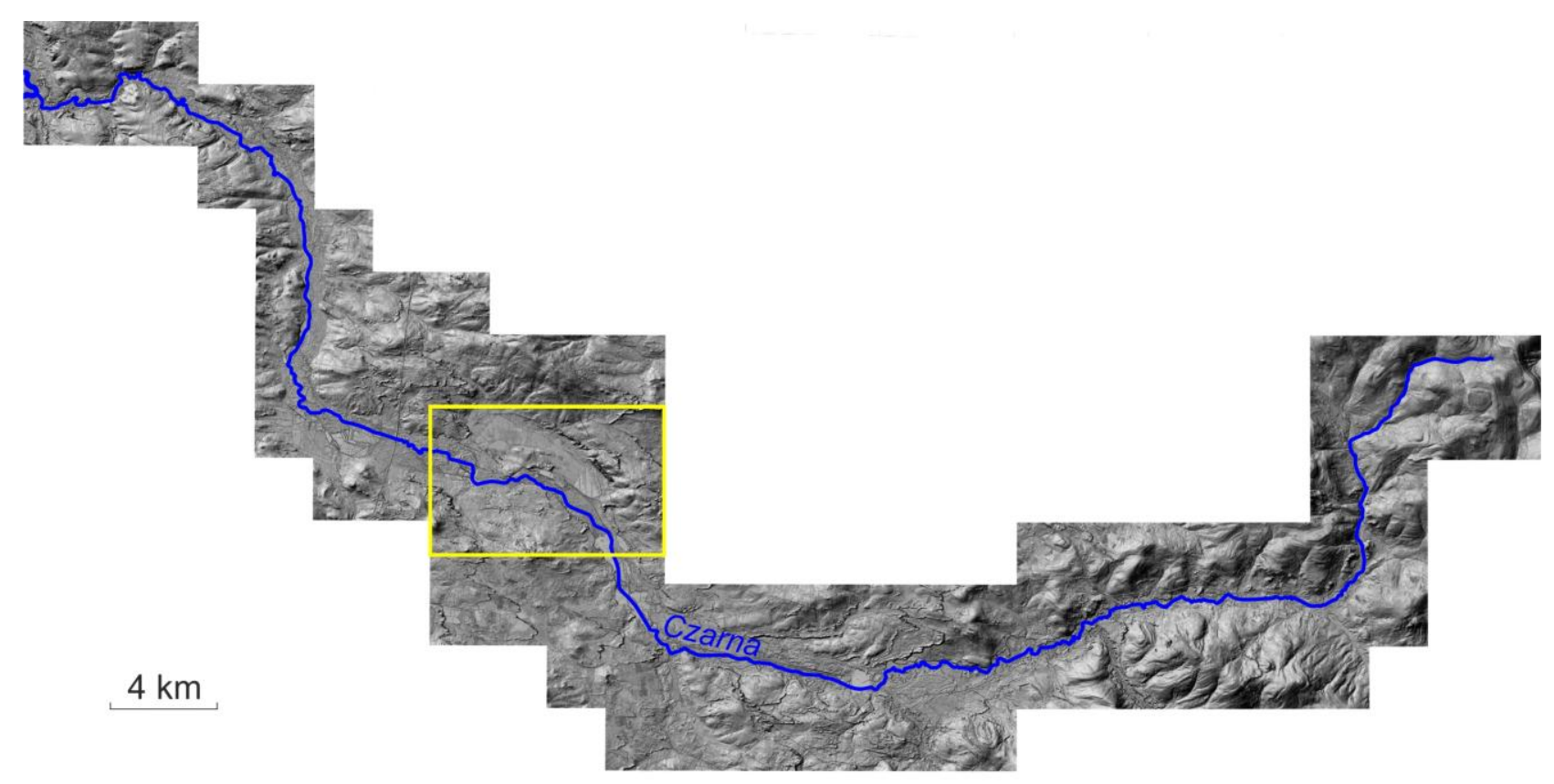

Fig. 3. DEMs of the River Czarna valley and adjacent areas under study. Detailed study area (around Maleniec, Kołoniec and Machory ironworks) marked in yellow

\subsection{Identifying traces of charcoal kilns in the field}

Occurrence of 20 selected traces of charcoal kilns, earlier identified from DEM images, was verified through field study. Soil profiles of kiln remnants were analysed in test pits to check for evidence of charcoal production. Profiles were prepared in the central elevation of each mound a probable former charcoal kiln. It was assumed that if charcoal and/or charcoal dust were present in the profile, then a charcoal kiln operated in the tested place in the past.

\subsection{Radiocarbon dating and palaeobotanical analysis of charcoal}

We extracted fragments of charcoal for radiocarbon dating from three charcoal kilns found on DEM and in the field (Fig. 4). Three charcoal samples were dated in the Laboratory of Absolute Dating, Cracow, Poland (laboratory code: MKL). Samples were also the subject of palaeobotanical analysis prior to $14 \mathrm{C}$ dating in order to determine the species of burnt wood. Two samples (M1, M2) contained one bigger piece of burnt wood each and the third sample (M3) contained three smaller fragments of carbon.

During the palaeobotanical (anthracological) analysis we have measured each analysed piece of charcoal (along the longest dimension). Next charcoal pieces were split to obtain surfaces that would allow inspection of the anatomical features in the transverse, tangential and radial sections. The charcoal underwent taxonomic identification based on observations of the wood anatomy at a magnification of 100-500x. Charcoals were observed in reflected light under a metallographic microscope (Olympus BX53M) and using micro-imaging software (Stream Essentials 2.1). The morphological characteristics of analysed charcoal fragments were compared with the anatomy of contemporary specimens available in the comparative collection of plant macrofossils (Silesian Museum, Katowice, Poland) and presented by SCHWIENGRUBER (1978).

\section{Results}

Numerous convex, circular items c $0.5 \mathrm{~m}$ high (measured in the central part of each item) were identified from DEM images developed using diverse GIS techniques. Those mounds are usually surrounded by smaller hollows (c 10 to $20 \mathrm{~cm}$ deep). The diameter of the mounds is on average $12-16 \mathrm{~m}$, and the diameter of each hollow is $2-3 \mathrm{~m}$. Depending on the size of a mound, the number of hollows ranges from 4 to 8 . The DEM analysis shows that the total number of such mounds, probably charcoal kilns, in the study area exceeded 11,500. Spatial distribution of charcoal kilns in the studied area is uneven. In some areas (e.g. in the lower most section of the Czarna valley or on arable areas) kiln remnants are absent, but in some places (e.g. area nearby ironworks) their number reaches as many as 95 per $1 \mathrm{~km}^{2}$. 


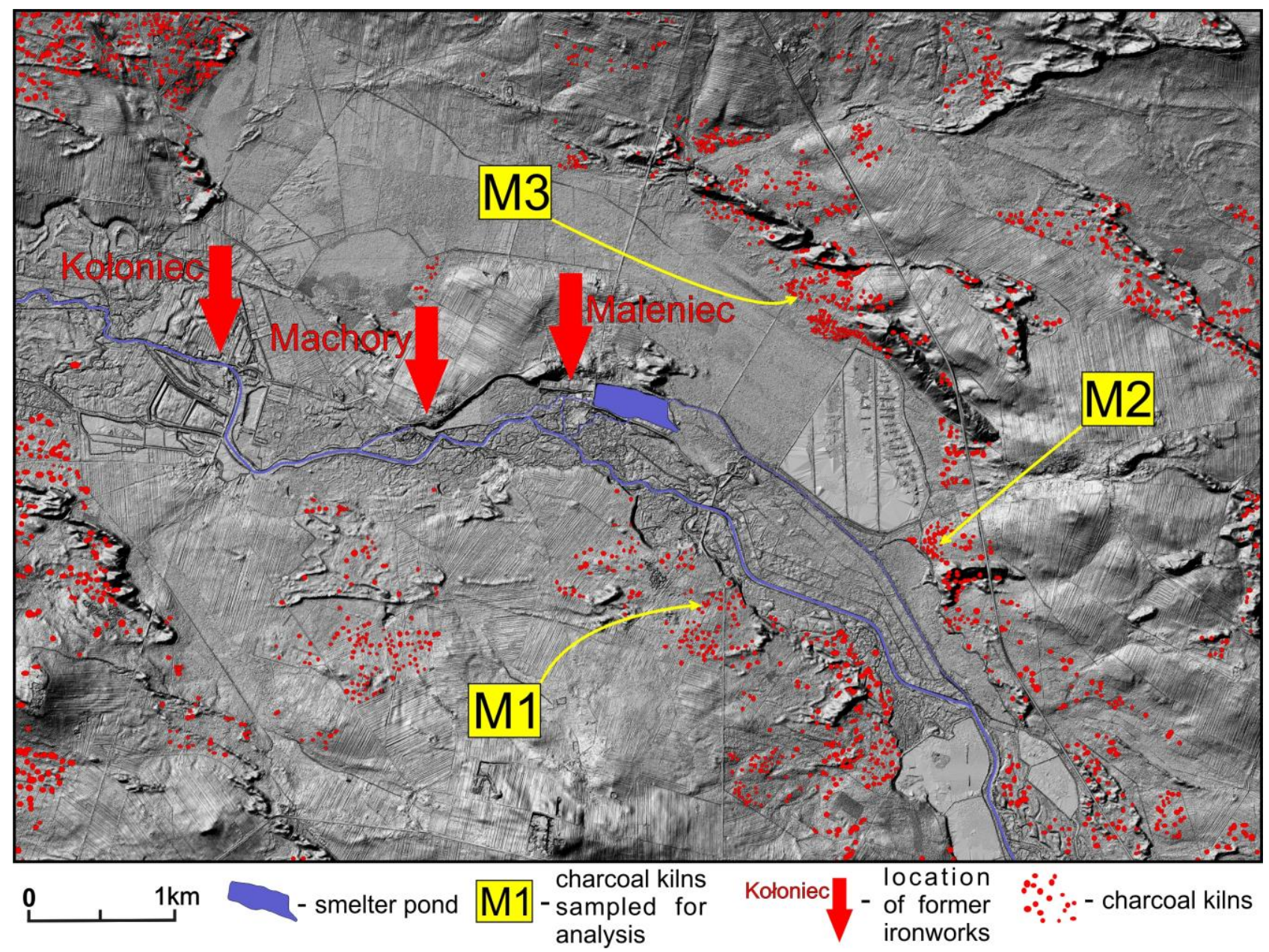

Fig. 4. Part of the River Czarna valley studied in detail with objects related to ferrous processing

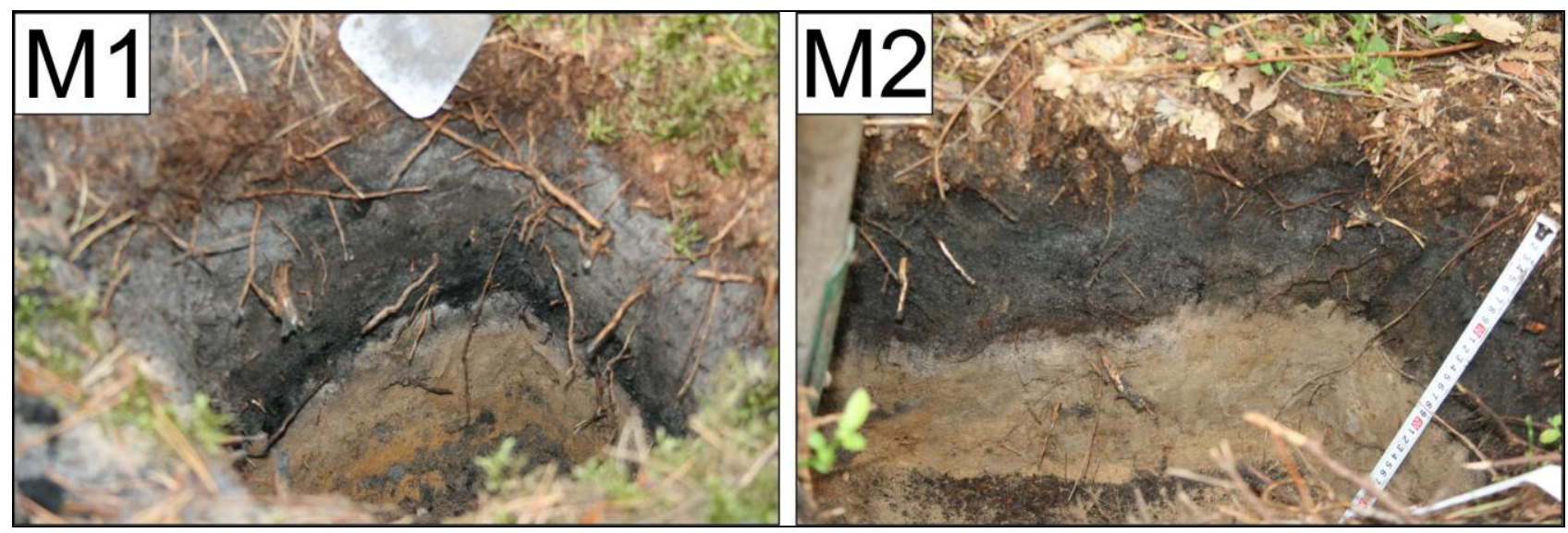

Fig. 5. Examples of the charcoal kiln structure with characteristic black layers of ash with abundant small pieces of charcoal (M1, M2 - kilns sampled for radiocarbon dating and palaeobotanical analysis)

During the field work charcoal and charcoal dust were found in each of the 20 tested mounds. The layer of charcoal in the mound examined was up to $25 \mathrm{~cm}$ thick and lies directly on sandy deposits (Fig. 5). The charcoal layer was always covered with forest litter. The size of single charcoal fragments in the kilns investigated varies from millimetres up to tens of centimetres. In some cases we found were several $10 \mathrm{~cm}$ fragments of burnt wood in one pit, however, smaller $(\mathrm{few} \mathrm{cm}$ ) charcoal fragments were the most common.

Results of radiocarbon dating revealed that charcoal sampled from M1, M2 and M3 kilns (Fig. 4) was probably produced in the $15^{\text {th }}, 18^{\text {th }}$ and $19^{\text {th }}$ century (Tab. 1). All analysed pieces of charcoal had relatively well preserved structures which facilitated species identification. Two samples analysed (M1 and M2) were identified as burnt wood of Scots pine (Pinus sylvestris) and the third 
sample (M3) was identified as charcoal from spruce or larch wood (Picea abies or Larix sp.) (Tab. 1). All three fragments of charcoal in the latter sample (M3) belonged to the same species, and they probably originated from one, larger piece.

The identification of burnt pieces of pine wood was carried out based on the following anatomical characteristics: wood composed of tracheids with resin ducts, large, open pits observed in the cross- fields on the radial section, ray tracheids with characteristic dentated walls (Fig. 6 I, Fig. 6 II). The wood from the M3 sample, described as burnt wood of spruce or larch, was identified based on the following characteristic features: wood composed of tracheids, resin ducts, small pits in cross-fields (Fig. 6 III, Fig. 6 IV). The anatomy does not allow a distinction between spruce and larch wood (see: SCHWIENGRUBER, 1978).

Tab. 1. Results of radiocarbon dating and palaeobotanical analysis obtained for the samples M1, M2 and M3

\begin{tabular}{|c|c|c|c|}
\hline $\begin{array}{c}\text { Location of charcoal kilns } \\
\text { sampled/laboratory code (Fig. 4) }\end{array}$ & Sample depth & $\begin{array}{c}\text { Tree species used for charcoal } \\
\text { burning }\end{array}$ & $\begin{array}{c}\text { C14 dating [BP]/calibrated } \\
\text { dating [AD] }\end{array}$ \\
\hline M1/MKL-3311 & $30 \mathrm{~cm}$ & $\begin{array}{c}\text { Scot pine } \\
\text { (Pinus sylvestris) }\end{array}$ & $500 \pm 35 / 1395-1450$ \\
\hline M2/MKL-3312 & $40 \mathrm{~cm}$ & $\begin{array}{c}\text { Scot pine } \\
\text { (Pinus sylvestris) }\end{array}$ & $190 \pm 35 / 1725-1815$ \\
\hline M3/MKL-3313 & $20-34 \mathrm{~cm}$ & $\begin{array}{c}\text { Spruce (Picea abies) or larch } \\
\text { (Larix sp.) }\end{array}$ & $130 \pm 35 / 1798-1895$ \\
\hline
\end{tabular}
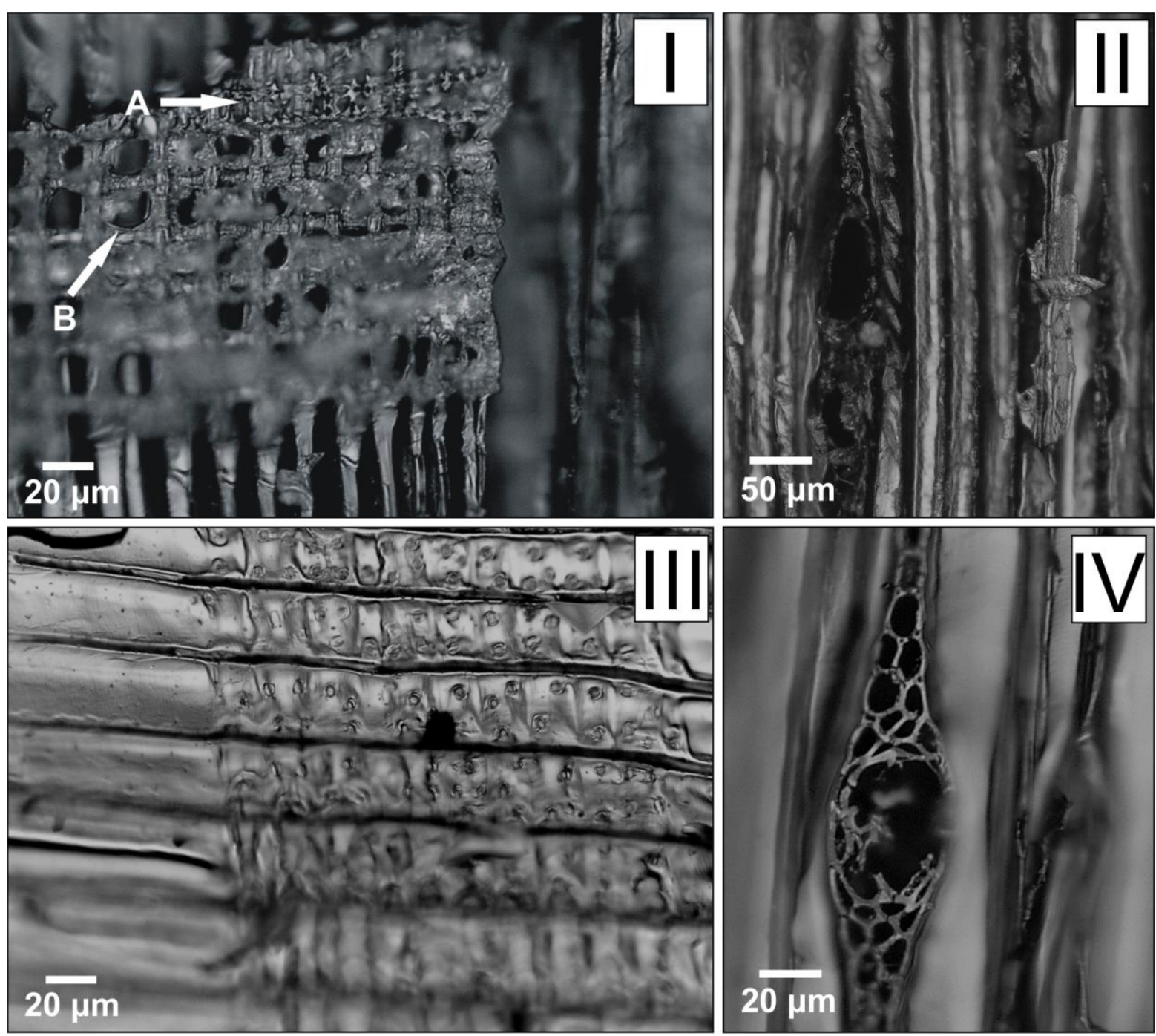

Fig. 6. Photo. I - radial section of burnt wood of Scots pine (Pinus sylvestris), Maleniec (M1 sample) (large pinoid pit per crossfield B and tooth-shaped walls of tracheids A); Photo. II - tangential section of burnt wood of Scots pine (Pinus sylvestris) Maleniec (M1 sample) (resin duct); Photo. III - radial section of Picea abies or Larix sp. burnt wood, Maleniec (M3 sample) (small pits in the cross-fields); Photo. IV - tangential section of Picea abies or Larix sp. burnt wood, Maleniec (M3 sample) (resin canal) 


\section{Discussion}

Remnants of charcoal kilns are almost imperceptible in the field. They can be recognized from LiDAR images if data resolution is high enough. Using a combination of several advanced imaging techniques (Multiple Hillshading from several directions, Local Relief Model (LRM), Sky-View Factor (SVF), Positive and Negative Openness (OPPOS and OPNEG) is the best technique to reveal traces of charcoal kilns: (Fig. 7, 8). Such a combination is particularly useful in areas where charcoal kilns are located close to one another. Using diverse image analysis technique limits the risk of omitting less distinct landforms (Fig. 8). Analysis of valley topography with more than one technique allows one to detect more items, as using one technique can often complement the other and reduce its limitations. In our research we mostly used the simplest hillshading method because of the well-preserved shape of the objects under study. However, the results show that all the tools applied, slightly varied in the details of visualization, are effective in detecting remnants of charcoal kilns. The basic method of visualizing LiDAR images as hillshading is justified only for complete, relatively undisturbed objects located at relatively large distances one form other (Fig. 7).
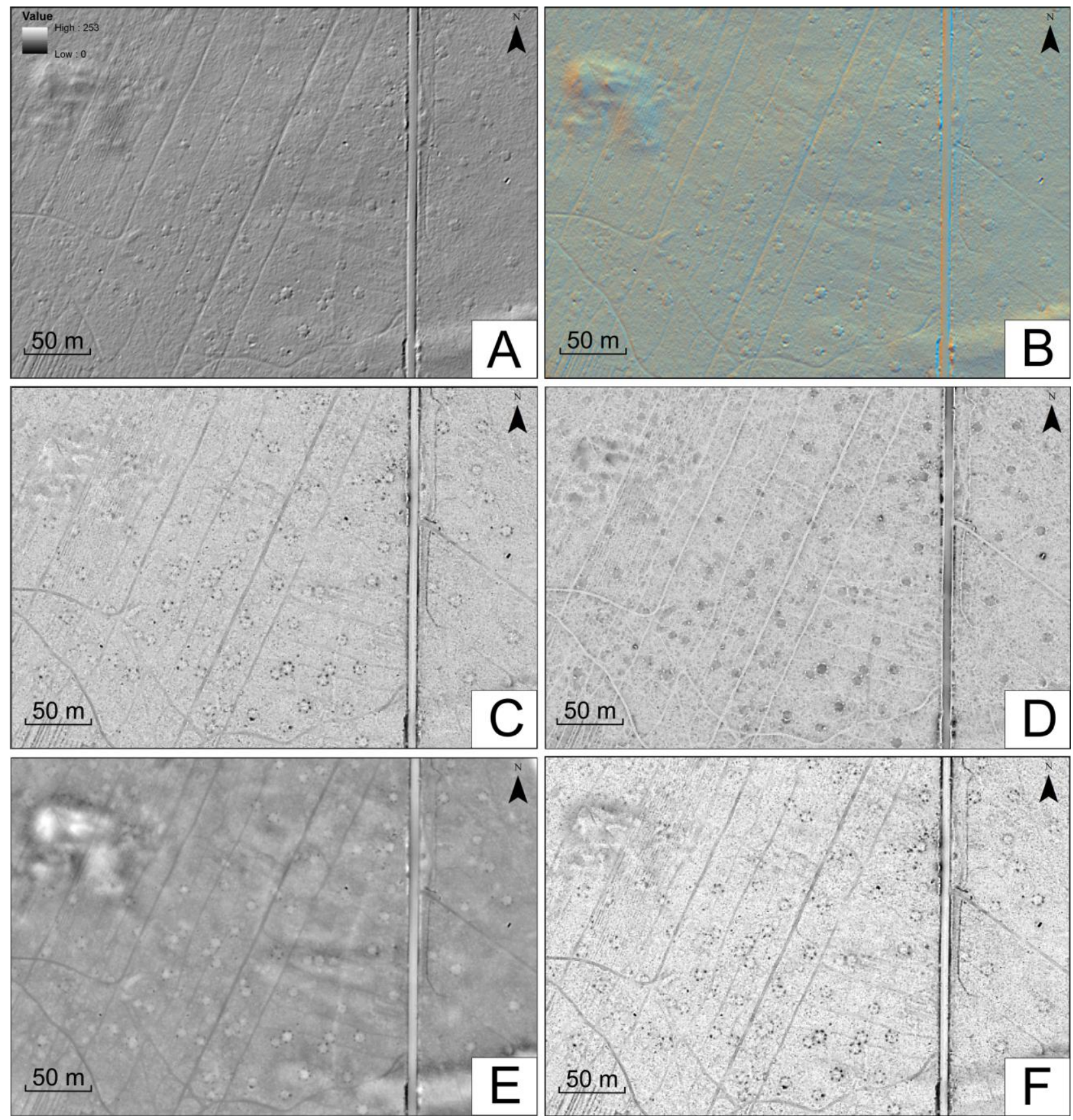

Fig. 7. Traces of charcoal kilns located at large distances from one another (at least several meters) on LiDAR images: A - hillshading; B - multiple hillshading; C - Positive Openness (OPPOS); D - Negative Openness (OPNEG); E - Local Relief Model (LRM); F - SkyView Factor (SVF). Used toolbox: Relief Visualization Toolbox, ver. 1.3, (Kokalj et al., 2013) 

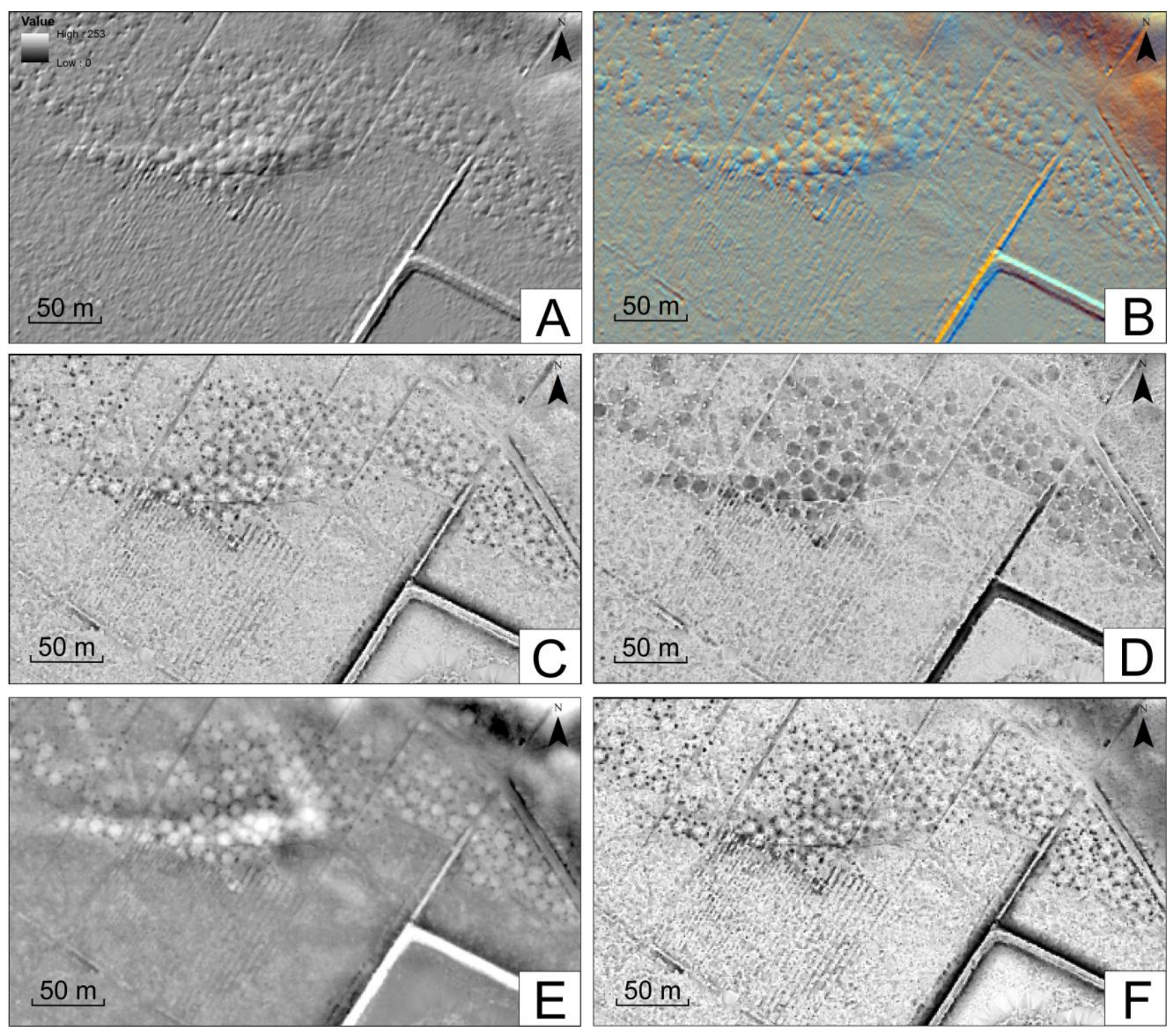

Fig. 8. Traces of charcoal kilns located close to one another on LiDAR images: A - hillshading; B - Multiple Hillshading; C - Positive Openness (OPPOS); D - Negative Openness (OPNEG); E - Local Relief Model (LRM); F - Sky-View Factor (SVF). Used toolbox: Relief Visualization Toolbox, ver. 1.3, (Kokalj et al., 2013)

There are other examples of successful usage of advanced GIS techniques for automatically detection of archaeological objects. BAKUŁA ET AL. (2014) demonstrated the effectiveness of the Local Relief Model, along with the field-based diagnosis of charcoal kiln remnants in the test area, indicates a $77 \%$ effectiveness in detecting objects. TRIER ET AL. (2012) indicate that the accuracy of automatic detection of archaeological objects can be as high as $94 \%$. However, the automatic detection of archaeological objects is considered rather as supporting analysis, complementary to other methods, example e.g. sedimentological analyses or charcoal dating (BAKUŁA ET AL., 2014). Apart from the terrain morphology the dark layer of ash and charcoal in the sediment is diagnostic for charcoal kilns. LUDEMANN (2012) has shown that historical sites of charcoal burning (charcoal kiln sites) with their distinct anthropogenic structure of soil and charcoal layers are widespread, in particular in forested mountainous regions. Our study has shown that remnants of charcoal kilns are also common in river valleys flowing through upland areas and in adjacent areas.

The results of radiocarbon dating indicate that charcoal production was conducted in the studied area in the $15^{\text {th }}, 18^{\text {th }}$ and $19^{\text {th }}$ century. Probably, a larger number of dates would allow identification of charcoal kilns from the $16^{\text {th }}$ and $17^{\text {th }}$ century and a continuous charcoal production in the study area which lasted for at least 500 years. According to RÖSLER ET AL. (2012) charcoal kilns in Europe were used between the $16^{\text {th }}$ to the $19^{\text {th }}$ century. In Poland charcoal kilns in the Mała Panew valley were dated at the turn of the $18^{\text {th }}$ centuries (MALIK ET AL., 2015). The results of radiocarbon dating confirm the information from historical written sources which describe the presence of iron industry centres in Maleniec, Machory and Kołoniec in the $18^{\text {th }}$ and $19^{\text {th }}$ century. It is interesting that the 
charcoal kiln dated to the $15^{\text {th }}$ century is located close to the iron smelters under study. It shows that the charcoal in the study area was already produced in the $15^{\text {th }}$ century, but it is not known for which smelter. This may have been the Machory or Kołoniec smelters which, according to historical sources, already existed in the $16^{\text {th }}$ century, in 1510. The radiocarbon age of charcoal suggests that at least one of the ironworks under study is at least several decades, or a century, older than 1510. A similar case occurred in Kuczów (River Mała Panew, Silesian Upland, Poland), probably the oldest iron smelter in Silesia and also one of the first on Polish territory. Its location has not yet been determined despite historical descriptions (KALINOWSKI, 2015). It is also possible that another metallurgical centre operated nearby but was not mentioned in historical sources. Numerous small smelters, not able to compete with larger centres, often declined and ceased to operate, and were not recorded by historians.

The large number of charcoal kilns and the vast area they cover indicate the large scale of charcoal production for the ironworks in the River Czarna valley. Large amounts of charcoal were used for iron smelting: c 9 tons of charcoal were necessary to melt 1 ton of iron (RAJMAN, 2009). Charcoal production was carried out for many centuries and probably could have resulted in almost complete deforestation of areas around the iron smelters.

Charcoal kilns located in the River Czarna valley, and in the adjacent areas, were relatively large, at least several metres in diameter. Hollows distributed around each charcoal kiln - are probably traces of inlets allowing temperature control and regulating air inflow into a kiln (TYROL, 2006).

Charcoal kilns were located directly in logging areas. Charcoal was burnt several times at one place, saving the time necessary for digging new inlets for temperature and air control. Places of charcoal production changed with the availability of wood. Once all the trees in an area were utilized charcoal kilns were abandoned and new ones were constructed to avoid the need to transport unburnt wood (TYROL, 2006).

The analysis of the species composition of extracted charcoal fragments shows that pines, spruce or larch trees were used for charcoal production as indicated by the presence of burnt wood of these mentioned species in kiln remnants. It is also evidence of the presence of mentioned the taxa in tree stands in the study area, directly around charcoal kilns under study and at the same time as the kilns operated. According to СНŁOРЕК (2015a) in the middle of the $19^{\text {th }}$ century the following species of tree were growing in the studied area: pine $(70 \%)$, fir $(8.75 \%)$, spruce $(6.25 \%)$. There is no data on the species composition of forests before the $19^{\text {th }}$ century. The lack of other species in the analysed material cannot serve as a basis for a statement that conifer wood was the main or only burnt material. Although literature indicates that deciduous species were mainly selected for charcoal production, this probably depended on the area of logging. In the $18^{\text {th }}$ and $19^{\text {th }}$ century charcoal was divided into two types: hard and soft. Hard charcoal, valuable and more desirable, was obtained from oak, beech, hornbeam and ash. Soft charcoal was obtained from burning birch wood, alders, aspen, larch and pine (PASCHALIS, 1973).

\section{Conclusions}

1. With the use of various types of DEM images over 11.500 single mounds - traces of charcoal kilns were identified in the studied area. DEM images generated from airborne LiDAR data allow simple and relatively quick identification and inventory of the remnants past charcoal production.

2. Radiocarbon dating indicates that charcoal kilns operated in the studied area in the $15^{\text {th }}, 18^{\text {th }}$ and $19^{\text {th }}$ century. Results prove that the iron industry in the River Czarna valley could be 100 years older than the historical written sources indicate. 3. Analysis of the species composition of charcoals collected from kilns has shown the presence of pine and spruce/larch wood. It indicates the use of these mentioned taxa for the production of charcoal and the presence of Scots pine and Norway Spruce or larch in tree stands around the analysed ironworks.

4. The large number of charcoal kilns, and the vast area they cover, indicate that the past charcoal production has had a significant impact on the environment of studied area and changed the landscape of the River Czarna valley and adjacent areas.

\section{Acknowledgements}

The study was partially funded by the Faculty of Earth Sciences, University of Silesia in Katowice from the subsidy of the Polish Ministry of Science and Higher Education for research and development works carried out by young scientists or PhD students in the field of Earth sciences. Part of the study was funded within the scope of the research project no. 2011/01/B/ST10/00548 funded by the Polish National Science Centre.

\section{References}

Bakuła K., Ostrowski W., Zapłata R. 2014. Automatyzacja w procesie detekcji obiektów archeologicznych $\mathrm{z}$ danych ALS. FPP, 19: 189-206. 
Bal M.C., Allée P., Liard M. 2015. The origins of a Nardus stricta grassland through soil charcoal analyses: Reconstructing the history of a mountain cultural landscape (Mont Lozère, France) since the Neolithic. Quat. Int., 366: 3-14.

Bielenin K. 1960. Badania nad starożytnym hutnictwem świętokrzyskim w 1958 r. Mat. Archeol. II. Muzeum Archeol. w Krakowie, Kraków.

Borchard N., Ladd B., Eschemann S., Hegenberg D., Möseler B.M., Amelung W. 2014. Black carbon and soil properties at historical charcoal production sites in Germany. Geoderma, 232: 236-242.

Chłopek M. 2015a. Maleniecka fabryka żelaza: infrastruktura i wyposażenie na przestrzeni wieków. bp. [in:] Zbiory ZZH w Maleńcu. Maleniec.

Chłopek M. 2015b. Surowizna, łańcuchy, gwoździe i łopaty.. wyroby i produkty wytwarzane w dobrach Ruda Maleniecka (XVIII-XIX w.). bp. [in:] Zbiory ZZH w Maleńcu. Maleniec.

Chłopek M. 2015c. Warunki naturalne i przyrodnicze do rozwoju metalurgii i hutnictwa w okolicach Rudy Malenieckiej (XVIII-XX w.). bp. [in:] Zbiory ZZH w Maleńcu. Maleniec.

Chrzanowski W. 1859. Karta dawnej Polski, 1:300 000.

Deforce K., Boeren I., Adriaenssens S., Bastiaens J., De Keersmaeker L., Haneca K., Vandekerkhove K. 2013. Selective woodland exploitation for charcoal production. A detailed analysis of charcoal kiln remains (ca. 13001900 AD) from Zoersel (northern Belgium). J. Archaeol. Sci., 40 (1): 681-689.

Delhon C., Moreau C., Magnin F., Howarth L. 2017. Rotten posts and selected fuel: Charcoal analysis of the first Middle Neolithic village identified in Provence (Cazan-Le Clos du Moulin, Vernègues, Bouches-du-Rhône, South of France). Quat. Int., (in press).

Dupin A., Girardclos O., Fruchart C., Laplaige C., Nuninger L., Dufraisse A., Gauthier E. 2017. Anthracology of charcoal kilns in the forest of Chailluz (France) as a tool to understand Franche-Comte forestry from the mid-15th to the early 20th century AD. Quat. Int., (in press).

Gale R. 2003. Wood-based industrial fuels and their environmental impact in lowland Britain. [in:] Murphy P., Wiltshire P.E.J. (eds.) The Environmental Archaeology of Industry. Symp. Ass. Environ. Arch., 20. Oxbow Books, Oxford: 3047.

Gąsiorowska N. 1937. Górnictwo i hutnictwo w Polsce. PWKS, Lwów.

Gilly Special Karte von Südpreussen, 1:150 000, 1803.

Goszyk E. 2001. Kartki z dziejów żelaznego Bruśka. Brusiek.

Groenewoudt B. 2007. Charcoal burning and landscape dynamics in the Early Medieval Netherlands, in Arts and Crafts in Medieval Rural Environment. Brepols Pub., 6: 327-337.

Herbst S. 1951. Walcownia w Maleńcu. Ochrona Zabytków, 34: 119-126.

Hesse R. 2010. LiDAR-derived Local Relief Models a new tool for archaeological prospection. Archaeol. Prospect., 17: 67-72.

Kalinowski P. 2015. Dzieje wioski Kuczów. Kalety.

Knapp H., Robin V., Kirleis W., Nelle O. 2013. Woodland history in the upper Harz Mountains revealed by kiln site, soil sediment and peat charcoal analyses. Quat. Int., 289: 88-100.

Kokalj Ž., K., Zakšek K., Oštir K. 2011. Application of Sky View Factor for the Visualization of Historic Landscape Features in Lidar - Derived Relief Models. Antiquity, 85 (327): 263-273.

Kondracki J. 2000. Geografia regionalna polski. PWN, Warszawa.

Kubicki R., Saletra W. 2013. Hutnictwo i górnictwo w regionie świętokrzyskim - do Księstwa Warszawskiego. SiM Miscellanea Oeconomicae, 17 (2): 29-40.

Ludemann T. 2002. Anthracology and forest sites - the contribution of charcoal analysis to our knowledge of natural forest vegetation in south-west Germany. BAR Int. Series, 1063: 209-217.

Ludemann T. 2003. Large-scale reconstruction of ancient forest vegetation by anthracology-a contribution from the Black Forest. Phytocoenologia, 33 (4): 645-666.

Ludemann T. 2010. Past fuel wood exploitation and natural forest vegetation in the Black Forest, the Vosges and neighbouring regions in western Central Europe. Palaeogeogr. Palaeoclimatol. Palaeoecol., 291 (1/2): 154-165.

Ludemann T. 2011. Scanning the historical and scientific significance of charcoal production - local scale, high resolution kiln site anthracology at the landscape level. SAGVNTVM Extra, 11: 23-24.

Ludemann T. 2012. Airborn laser scanning of historical wood charcoal production sites - a new tool of kiln site anthracology at the landscape level. SAGVNTVM Extra, 13: $247-252$.

Ludemann T. Michiels H.G., Nölken W. 2004. Spatial patterns of past wood exploitation, natural wood supply and growth conditions: indications of natural tree species distribution by anthracological studies of charcoal-burning remains. Eur. J. Forest Res., 123: 283-292.

Malik I., Opała M., Wistuba M., Franek M., Tyrol C., Manczyk G., Bielarczyk P. 2014. Rekonstrukcja funkcjonowania historycznego hutnictwa żelaza na podstawie datowania dendrochronologicznego pozostałości budowli drewnianych i węgli drzewnych z mielerzy (Równina Opolska). SiM CEPL, 16 (3 [40]).

Malik I., Wistuba M., Opała M., Franek M., Woskowicz-Ślęzak B., Mańczyk G., Tyrol C. 2015. Historical water-powered ferrous metallurgy reconstructed from tree-rings and lacustrine deposits (Mała Panew basin, southern Poland). Geochronometria, 42: 79-90.

Marszałek E., Kusiak W. 2013. Wypał węgla drzewnego w Bieszczadach w przeszłości i obecnie. Rocz. Bieszczadzkie, 1(21): 164-183.

Mayoral A., Toumazet J.P., Simon F.X., Vautier F., Peiry J.L. 2017. The Highest Gradient Model: A New Method for Analytical Assessment of the Efficiency of LiDAR-Derived Visualization Techniques for Landform Detection and Mapping. Remote Sens., 9: 1-120.

Nelle 0. 2003. Woodland history of the last 500 years revealed by anthracological studies of charcoal kiln sites in the Bavarian Forest, Germany. Phytocoenologia, 33 (4): 667-682.

Orłowski M. 1931. Żelazny przemysł hutniczy na ziemiach polskich do r. 1914. Warszawa.

Paschalis J. 1973. O węglach do hut i kuźnic. Sylwan, 1: 41-46.

Raab A., Takla M., Raab T., Nicolay A., Schneider A., Rösler H., Bönisch E. 2015. Pre-industrial charcoal production in Lower Lusatia (Brandenburg, Germany): Detection and evaluation of a large charcoal-burning field by combining archaeological studies, GIS-based analyses of shadedrelief maps and dendrochronological age determination. Quat. Int., 367: 111-122.

Radwan M.W. 1963. Rudy, kuźnice i huty żelaza w Polsce. W. Naukowo-Techniczne.

Rajman J. 2009. Dzieje hutnictwa żelaza na środkową Małą Panwią. [in:] Szulc J. (ed.) $Z$ biegiem Małej Panwi $Z$ biegiem lat. Żędowice-Kraków: 94-103.

Rösler H., Bönisch E., Schopper F., Raab T., Raab A. 2012. Preindustrial charcoal production in southern Brandenburg and its impact on the environment. [in:] Kluiving S.J., Guttmann-Bond E.B. (eds.) Landscape Archaeology between Art and Science. From a Multi- to an Interdisciplinary Approach: 167-178.

Schoch W.H. 2012. Information content of Anthracology. SAGVNTVM Extra, 13: 259-267. 
Schwiengruber F.H. 1978. Mikroskopische Holzanatomie. Eidgenössische Anstalt für das forstliche Versuchswesen. Kommissionsverlag Zürcher AG, Zug.

Szczegółowa mapa geologiczna Polski 1:50 000 I. Jurkiewicz 1965. Arkusz Radoszyce.

Szczegółowa mapa geologiczna Polski 1:50 000 R. Krajewski 1955. Arkusz Odrowąż.

Tolksdorf J. F., Elburg R., Schröder F., Knapp H., Herbig C., Westphal T., Hemker C. 2015. Forest exploitation for charcoal production and timber since the 12 th century in an intact medieval mining site in the Niederpöbel Valley (Erzgebirge, Eastern Germany). J. Archaeol. Sci.: Reports, 4: 487-500.

Trier Ø.D., Zortea M., Larsen S.Ø. 2012. Semi-automatic detection of burial mounds in forested areas [in:] Perakis K.G.,
Moysiadis A.K. (eds.) European Association of Remote Sensing Laboratories. 32nd EARSeL Symp. Proc. Adv. Geosci., Mykonos Island, Greece: 113-124.

Tyrol C. 2006. W leśnej dolinie Małej Panwi (In the woody valley of the Mała Panew River). Zespół Pieśni i Tańca „Śląsk” im. Stanisława Hadyny, Koszęcin.

Zapłata R., Borowski M. 2013. GIS w archeologii-przykład prospekcji i inwentaryzacji dziedzictwa archeologicznoprzemysłowego. Rocz. Geom., 11.4 (61): 103-112.

Zapłata R., Szady B., Stereńczak K. 2014. Laserowi odkrywcy: nieinwazyjne badanie $i$ dokumentowanie obiektów archeologicznych $i$ historycznych województwa świętokrzyskiego. Fund. Centrum Geohistorii, Stare Babice.

Zientara B. 1954. Dzieje małopolskiego hutnictwa żelaznego: 14-17 wiek. PWN, Warszawa. 